Article

\title{
Phosphate Removal from Secondary Effluents Using Coal Gangue Loaded with Zirconium Oxide
}

\author{
Jibing Xiong ${ }^{1,2, *}$, Li Zang ${ }^{1,2}$, Jianfeng Zha ${ }^{1,2, *}$, Qaisar Mahmood ${ }^{3}$ and Zhenli He ${ }^{4}$ \\ 1 Jiangsu Key Laboratory of Resources and Environmental information Engineering, \\ China University of Mining and Technology, Xuzhou 221116, China; TS17160014A3@cumt.edu.cn \\ 2 School of Environment Science and Spatial Informatics, China University of Mining and Technology, \\ Xuzhou 221116, China \\ 3 Department of Environmental Sciences, COMSATS Institute of Information Technology Abbottabad, \\ Abbottabad 22010, Pakistan; mahmoodzju@gmail.com \\ 4 Indian River Research and Education Center, Fort Pierce, Institute of Food and Agricultural Sciences (IFAS), \\ University of Florida, Fort Pierce, FL 34945, USA; zhe@ufl.edu \\ * Correspondence: xiongjib108@163.com (J.X.); Zhajianfeng@cumt.edu.cn (J.Z.); \\ Tel.: +86-516-83591312 (J.X. \& J.Z.)
}

Received: 3 April 2019; Accepted: 22 April 2019; Published: 26 April 2019

\begin{abstract}
Phosphorus from secondary effluents and coal gangue from coal mining have caused serious environmental problems. The feasibility of phosphate removal from secondary effluents using calcinated coal gangue loaded with zirconium oxide (CCG-Zr) was explored. Major influencing factors like the calcinated temperature, CCG-Zr ratio, adsorbent dose, time and solution $\mathrm{pH}$, etc. were investigated. Newly developed CCG-Zr accomplished a significantly higher phosphate removal for phosphate (93\%) compared with CCG (35\%) at a calcinated temperature of $600{ }^{\circ} \mathrm{C}$ and CCG-Zr mass ratio of 1:1. For CCG-Zr the maximum phosphate removal rate (93\%) was noted at an initial phosphate concentration of $2 \mathrm{mg} / \mathrm{L}$ within $20 \mathrm{~min}$. The CCG-Zr displayed a higher phosphate removal rate (85-98\%) over a wide range of solution $\mathrm{pH}(2.5 \sim 8.5)$. The adsorption isotherms fitted better to the Freundlich $(R 2=0.975)$ than the Langmuir model $(R 2=0.967)$. The maximum phosphate adsorption capacity of the CCG-Zr was $8.55 \mathrm{mg} / \mathrm{g}$. These results suggested that the CCG-Zr could potentially be applied for the phosphate removal from secondary effluents.
\end{abstract}

Keywords: low concentration phosphate; phosphate adsorption; coal gangue modification; wastes reuse

\section{Introduction}

Phosphorus is a limiting nutrient for algal growth and its excessive concentration in wastewater discharged into aquatic environments often causes serious eutrophication problems, namely harmful algal blooms, depletion of dissolved oxygen and decline of aquatic life, etc. [1,2]. The secondary effluents from a typical sewage treatment plant may contain $1.0-2.0 \mathrm{mg} / \mathrm{L}$ Phosphorus in an anaerobic-anoxic-oxic $\left(\mathrm{A}^{2} / \mathrm{O}\right)$ process [3], which contributes to eutrophication in the receiving water bodies [4]. Phosphorus in the secondary effluents is mostly present as phosphate. Consequently, phosphate needs to be removed from secondary effluents to control eutrophication of the receiving water bodies. The control of phosphate in secondary effluents has been widely investigated. Great attention has been paid to the utilization of industrial wastes or their modification for phosphate removal. Iron oxide tailings [5], lanthanum-doped mesoporous $\mathrm{SiO}_{2}$ [6], iron-nanoparticles-loaded Spondias purpurea seed waste [7], steel slag coated with sodium hydroxide [8], alum [9] and other waste materials or their modifications have been explored so far. The major advantages of using these wastes or their modifications for wastewater treatment are cost effectiveness and desired reuse. 
Coal gangue is one of the major solid wastes produced as a result of coal mining and its washing. Generally, the total discharge capacity of coal gangue can reach up to $10-15 \%$ of the total raw coal extraction [10]. In China, approximately 315 million tons of coal gangue is produced on annual basis, with a total piling of about 4.5 billion tons [11]. Disposal of such a huge quantity of solid waste requires a large landfill area which may also cause serious environmental problems [12-14]. Owing to major chemical constituents, coal gangue possesses $\mathrm{SiO}_{2}$ and $\mathrm{Al}_{2} \mathrm{O}_{3}$ with traces of surface $\mathrm{Fe}$ and other metals, and thus it may be a potential adsorbent for phosphate. Usually, coal gangue is calcinated for the activation of $\mathrm{Al}_{2} \mathrm{O}_{3}$ or traces of $\mathrm{Fe}$, etc. metals to enhance phosphate removal efficiencies $[15,16]$. However, calcinated coal gangue is still uninvestigated as a phosphate adsorbent for its lower phosphate removal efficiencies under calcination. On the other hand, zirconium oxide has been given more consideration for its high sorption selectivity for phosphate and higher resistance against action of acids, alkalis, oxidizing and reducing agents [2,17-23]. Calcinated coal gangue (CCG) modified by zirconium oxide may have better phosphate removal efficiency compared with calcinated coal gangue. However, very limited information is available so far on the phosphate adsorption on calcinated coal gangue modified by zirconium oxide (CCG-Zr). The objective of the present study was the preparation of CCG- $\mathrm{Zr}$ by $\mathrm{ZrOCl}_{2} \cdot 8 \mathrm{H}_{2} \mathrm{O} / \mathrm{CCG}$ mass ratio of $1: 1$ under different calcinated temperatures $\left(300 \sim 800{ }^{\circ} \mathrm{C}\right.$ ) and various $\mathrm{ZrOCl}_{2} \cdot 8 \mathrm{H}_{2} \mathrm{O} / \mathrm{CCG}$ mass ratios and testing the prepared material for phosphate adsorption. The effects of various influencing parameters on the phosphate adsorption were also investigated in batch experiments.

\section{Materials and Methods}

\subsection{Materials and Chemicals}

Coal gangue samples were obtained from a local coal mining area in China. Zirconium oxychloride $\left(\mathrm{ZrOCl}_{2} \cdot 8 \mathrm{H}_{2} \mathrm{O}\right.$ ) with the purity $>99.33 \%$ was purchased from Zibo Xinlvyuan Biochemical Co. (Zibo, China). Analytical grade $\mathrm{KH}_{2} \mathrm{PO}_{4}$ and $\mathrm{KCl}$ were used in the experiment.

\subsection{Preparation of CCG-Zr}

Coal gangue was calcinated at $750{ }^{\circ} \mathrm{C}$ in an oven under anoxic conditions for $2 \mathrm{~h}$ and passed through a 100-mesh sieve for use [24]. Calcinated coal gangue (100 g) was added to solutions containing different amount of $\mathrm{ZrOCl}_{2} \cdot 8 \mathrm{H}_{2} \mathrm{O}$ so that different $\mathrm{ZrOCl}_{2} \cdot 8 \mathrm{H}_{2} \mathrm{O} / \mathrm{CCG}$ mass ratios $(0 \%, 12.5 \%, 25.0 \%$, $50 \%, 100 \%$ ) could be prepared. After $40 \mathrm{~h}$, the calcinated coal gangue was taken out and dried at $90^{\circ} \mathrm{C}$ for $2 \mathrm{~h}$. The $\mathrm{ZrOCl}_{2} \cdot 8 \mathrm{H}_{2} \mathrm{O} / \mathrm{CCG}$ mass ratio $(50 \%)$ was calcinated at different calcinated temperatures $\left(300,400,500,600,700,800{ }^{\circ} \mathrm{C}\right)$ for $6 \mathrm{~h}$.

The effect of various calcinated temperatures $\left(300,400,500,600,700,800{ }^{\circ} \mathrm{C}\right)$ and $\mathrm{ZrOCl}_{2} \cdot 8 \mathrm{H}_{2} \mathrm{O} / \mathrm{CCG}$ mass ratios $(0 \%, 12.5 \%, 25.0 \%, 50 \%, 100 \%)$ on phosphate removal were examined for suitable calcinated temperatures and $\mathrm{ZrOCl}_{2} \cdot 8 \mathrm{H}_{2} \mathrm{O} / \mathrm{CCG}$ mass ratios (phosphate adsorptive conditions: $1 \mathrm{~g} \mathrm{CCG}-\mathrm{Zr} / 50 \mathrm{~mL}$ containing $2 \mathrm{mg} \mathrm{P} / \mathrm{L}$ solution, initial $\mathrm{pH} 2.5$, time: $2 \mathrm{~h}$ under $15^{\circ} \mathrm{C}$ and $180 \mathrm{rpm}$ ).

\subsection{Characterization of CCG-Zr and Analysis Methods}

The components in calcinated coal gangue (CCG) loaded with $\mathrm{ZrOCl}_{2} \cdot 8 \mathrm{H}_{2} \mathrm{O}$ at different calcinated temperatures were determined by S8 Tiger X-ray fluorescence spectrometers (Germany, Bruker) (Table 1 ) (in $\mathrm{wt} \%$ ). Mineralogical phase of CCG and CCG modified by $\mathrm{ZrOCl}_{2} \cdot 8 \mathrm{H}_{2} \mathrm{O}(\mathrm{CCG}-\mathrm{Zr}$ ) were determined by D8 Advance X-ray diffractometer (Germany, Bruker) and the results were presented (Figure 1).

Table 1. Chemical composition of fresh coal gangue (FCG) and calcinated coal gangue (CCG).

\begin{tabular}{ccccccccc}
\hline$\%$ & $\mathrm{SiO}_{2}$ & $\mathrm{Al}_{2} \mathbf{O}_{3}$ & $\mathrm{Fe}_{2} \mathbf{O}_{3}$ & $\mathrm{CaO}$ & $\mathbf{M g O}$ & $\mathrm{Na}_{\mathbf{2}} \mathbf{O}$ & $\mathbf{K}_{\mathbf{2}} \mathbf{O}$ & $\mathrm{C}$ \\
\hline FCG & 26.96 & 13.97 & 2.027 & 0.407 & 0.363 & 0.20 & 0.759 & 54.6 \\
CCG & 48.57 & 23.86 & 2.66 & 0.88 & 0.74 & 0.23 & 1.65 & 20.40 \\
\hline
\end{tabular}




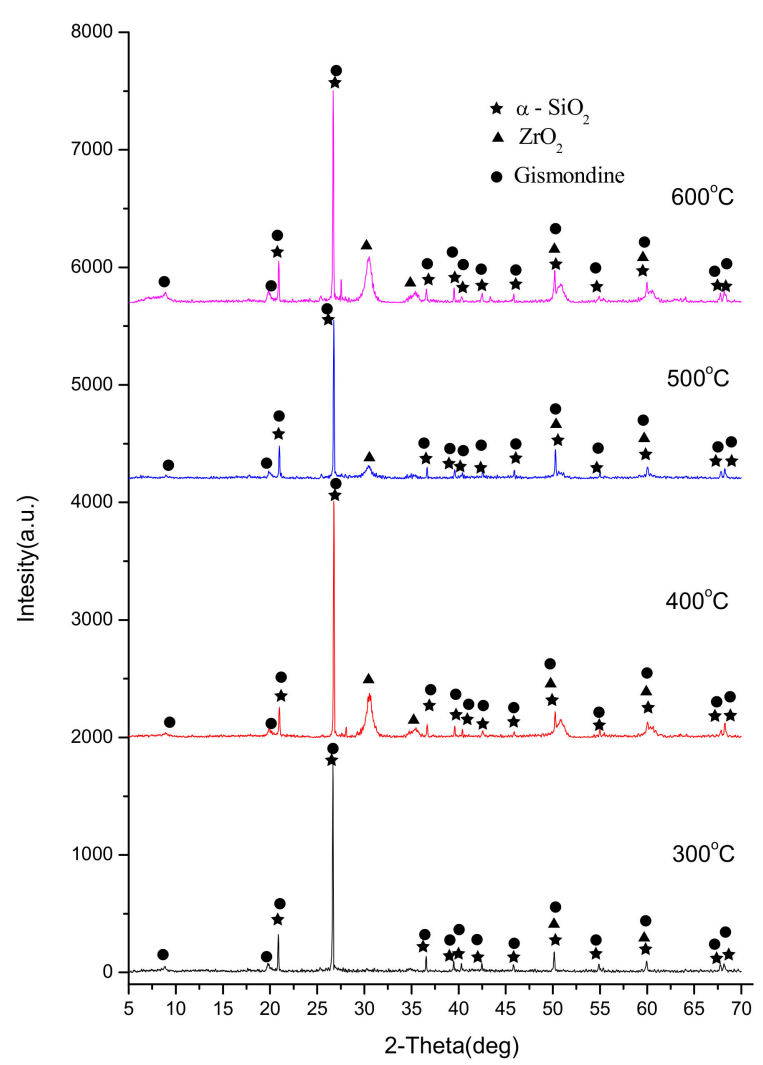

Figure 1. XRD patterns of coal gangue at different calcinated temperatures $\left(300^{\circ} \mathrm{C}, 400{ }^{\circ} \mathrm{C}, 500{ }^{\circ} \mathrm{C}\right.$, $\left.600{ }^{\circ} \mathrm{C}\right)$.

In the experimental studies, the phosphate concentrations in the solutions were measured through a UV-VIS spectrophotometer (Hitachi U-2800) following an ascorbic acid method as stated in the standard methods [25]. Solution $\mathrm{pH}$ was determined with Sartorius PB $220 \mathrm{pH}$ meter (Sartorius, Germany). The measurements were recorded in triplicate and the data were presented as the mean values at a $95 \%$ confidence interval.

\subsection{Phosphate Removal Experiment}

All the adsorption experiments were accomplished in batch mode of $150 \mathrm{~mL}$ conical flasks which were kept in shaker at $15^{\circ} \mathrm{C}$ set at $180 \mathrm{rpm}$. A background electrolyte of $0.01 \mathrm{~mol} / \mathrm{L} \mathrm{KCl}$ was used to adjust ionic strength in all the batch experiments. The samples were centrifuged at $5000 \mathrm{r} / \mathrm{min}$ for $10 \mathrm{~min}$ and a clear supernatant aliquot was collected to analyze phosphate concentration. A stock solution (50 mg L ${ }^{-1}$ ) of $\mathrm{KH}_{2} \mathrm{PO}_{4}$ was prepared by dissolving $0.2197 \mathrm{~g}$ in $1 \mathrm{~L}$ deionized water and dilutions of stock solution were administered in subsequent experiments. Phosphate concentrations from secondary effluents was simulated by diluting stock solution $\left(50 \mathrm{mg} \mathrm{L}^{-1}\right)$ of $\mathrm{KH}_{2} \mathrm{PO}_{4}$ to $2 \mathrm{mg} \mathrm{P} / \mathrm{L}$.

\subsubsection{Kinetic Experiments}

For all experiments, the adsorbent (CCG-Zr) dose was $1 \mathrm{~g}$ placed into each reaction flask containing $50 \mathrm{~mL}$ of phosphate solution ( $2 \mathrm{mg} \mathrm{P} / \mathrm{L}$ ). The sampling time intervals were 10, 20, 40, 60, 80, 100 and $120 \mathrm{~min}$. The operational conditions were: initial pH 2.5 under $15^{\circ} \mathrm{C}$ and $180 \mathrm{rpm}$. There were 21 same samples for 7 time interval in the kinetic experiment and three samples were taken out for phosphate concentration analysis every time. 


\subsubsection{Effect of $\mathrm{pH}$}

To study the effect of $\mathrm{pH}$, same adsorbent and adsorbate doses were used as for kinetics experiments. The effects of initial $\mathrm{pH}$ were investigated in the range of 2.5 to 11.5 . The initial solution $\mathrm{pH}$ was adjusted by using either $0.1 \mathrm{M} \mathrm{HCl}$ or $\mathrm{NaOH}$. All the flasks were capped to avoid evaporation and the $\mathrm{pH}$ values were analyzed after $2 \mathrm{~h}$ at $15^{\circ} \mathrm{C}$.

\subsubsection{Effect of Dosage}

Phosphate solution ( $2 \mathrm{mg} \mathrm{P} / \mathrm{L}$ ) was used for adsorption under varying doses of CCG- $\mathrm{Zr}$ (under initial pH 3.5, $15^{\circ} \mathrm{C}, 180 \mathrm{rpm}$ for $\left.2 \mathrm{~h}\right)$. The CCG-Zr doses were in range of 1 to $60 \mathrm{~g} / \mathrm{L}(1,5,10,20,40$, and $60 \mathrm{~g} / \mathrm{L})$.

\subsubsection{Isotherms Experiment}

Isotherm experiments were conducted using $0.5 \mathrm{~g}$ of CCG-Zr into conical flasks containing $50 \mathrm{~mL}$ phosphate solutions. The initial phosphate concentrations ranged from 2.5 to $50 \mathrm{mg} \mathrm{P} / \mathrm{L}(2.5,5,10$, $20,30,40$, and $50 \mathrm{mg} \mathrm{P} / \mathrm{L}$ ) at initial $\mathrm{pH}$ value of 3.5. The conical flasks were placed in the constant temperature shaker $\left(15^{\circ} \mathrm{C}\right.$ and $\left.180 \mathrm{rpm}\right)$ for $120 \mathrm{~min}$.

\subsubsection{Regeneration of Adsorbent}

The regeneration tests were carried out using CCG-Zr (50\%) with $2 \mathrm{mg} \mathrm{P} / \mathrm{L}$ of phosphate solution. After adsorption, the CCG-Zr (50\%) was collected and used for desorption studies. Different concentrations of $\mathrm{NaOH}(0.1,0.2,0.3,0.4$, and $0.5 \mathrm{M})$ were utilized to test the possibility of CCG-Zr regeneration.

\subsection{Data Processing}

All the treatments and analysis were conducted in triplicate. Differences in the results were statistically analyzed using one-way ANOVA (S-N-K) test (SPSS 18.0) at $p<0.05$.

\section{Results and Discussion}

\subsection{Characterization of CCG-Zr}

As shown in Table $1, \mathrm{Al}_{2} \mathrm{O}_{3}$ content of calcinated coal gangue at $750{ }^{\circ} \mathrm{C}$ increased by $70.79 \%$, while carbon content decreased by $62.64 \%$ compared with those in fresh coal gangue. The XRD patterns of CCG-Zr under different calcinated temperatures were illustrated in Figure 1, The major crystalline phase of CCG-Zr under different temperatures contained $\alpha-\mathrm{S}_{\mathrm{i}} \mathrm{O}_{2}$, Gismondine and $\mathrm{ZrO}{ }_{2}$. From Figure 1 it was evident that the peak assigned to quartz in these CCG-Zr was more intense which was attributed to its higher quartz content in these samples (Table 1). After exposure to different calcinated temperatures, several $\mathrm{ZrO}_{2}$ characteristic peaks were evident at $30^{\circ}, 35^{\circ}, 50^{\circ}$ and $60^{\circ}$ in the XRD pattern of CCG-Zr (Figure 1) according to ICDD (International Centre for Diffraction Data) card No. 34-1084, 50-1089, and 37-1413. This observation verified the presence of $\mathrm{ZrO}_{2}$ in CCG-Zr after the modification and calcination of $\mathrm{ZrOCl}_{2} \cdot 8 \mathrm{H}_{2} \mathrm{O}$. XRD of CCG-Zr at $300^{\circ} \mathrm{C}$ only showed two weak peaks at $50^{\circ}$ and $60^{\circ}$, respectively. It indicated that although $\mathrm{ZrO}_{2}$ began to appear in an orthorhombic state [26], it was not well crystallized at $300^{\circ} \mathrm{C}$ calcination which was supported by the low number and intensity of the orthorhombic $\mathrm{ZrO}_{2}$ XRD peak in CCG-Zr at $300{ }^{\circ} \mathrm{C}$. $\mathrm{ZrO}_{2}$ mainly exists in tetrahedron crystalline or coexists in tetragonal and orthorhombic crystalline at 400,500 , and $600{ }^{\circ} \mathrm{C}$ [26].

\subsection{Effect of Calcinated Temperature and $\mathrm{ZrOCl}_{2} \cdot 8 \mathrm{H}_{2} \mathrm{O} / \mathrm{CCG}$ Mass Ratio}

Under experimental conditions ( $2 \mathrm{mg} \mathrm{P} / \mathrm{L}, 20 \mathrm{~g} / \mathrm{L}$ absorbent dose, and contact time of $2 \mathrm{~h}$ ), all the calcinated coal gangue loaded with $\mathrm{ZrOCl}_{2} \cdot 8 \mathrm{H}_{2} \mathrm{O}\left(\mathrm{ZrOCl}_{2} \cdot 8 \mathrm{H}_{2} \mathrm{O} / \mathrm{CCG}(50 \%)\right)$ showed good performance regarding the phosphate removal with a phosphate removal efficiency of $88-93 \%$ while a 
slight increase in calcinated temperatures resulted in significantly enhancing phosphate adsorption on the coal gangue-zicornia oxide composite material (Figure 2a) $(p<0.05)$. It was evident from Figure 1 that orthorhombic $\mathrm{ZrO}_{2}$ at $300{ }^{\circ} \mathrm{C}$ turned into tetrahedral crystal or coexisted in tetrahedral and orthorhombic crystal at over $400{ }^{\circ} \mathrm{C}$. Tetrahedral $\mathrm{ZrO}_{2}$ crystal might have better affinities toward phosphate compared with orthorhombic $\mathrm{ZrO}_{2}$. Phosphate adsorption rapidly increased from $35 \%$ to $93 \%$ with an increasing $\mathrm{Zr} / \mathrm{CCG}$ mass ratio from $0 \%$ up to $50 \%$, indicative of enhanced phosphate adsorption caused by $\mathrm{ZrO}_{2}$ addition. Further increasing that ratio from $50 \%$ to $100 \%$ only raised the phosphate removal efficiency by approximately $2 \%$ (Figure $2 b)(p<0.05)$. It might be due to fixed amount of adsorption sites in CCG which could not completely adsorb the excess dosage of $\mathrm{Zr}$. Similar effects of lanthanum-doped mesoporous $\mathrm{SiO}_{2}$ on the adsorption of phosphate have also been previously reported by Ou et al. [6]. Calcinated temperature $\left(600{ }^{\circ} \mathrm{C}\right)$ and the $\mathrm{ZrOCl}_{2} \cdot 8 \mathrm{H}_{2} \mathrm{O} / \mathrm{CCG}$ mass ratio $(50 \%)$ were chosen in the following phosphate adsorption experiments, considering both phosphate removal efficiencies and cost effectiveness.

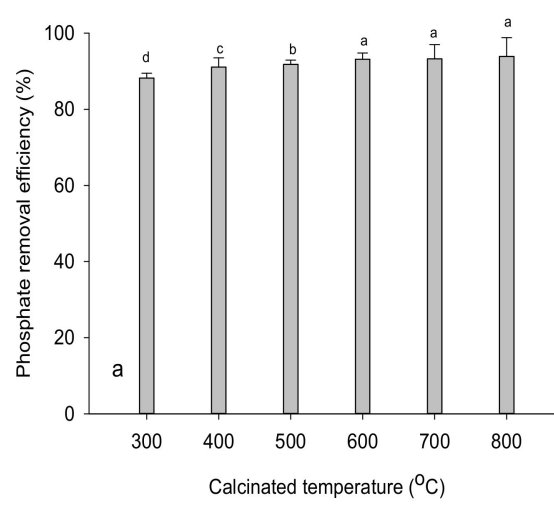

(a)

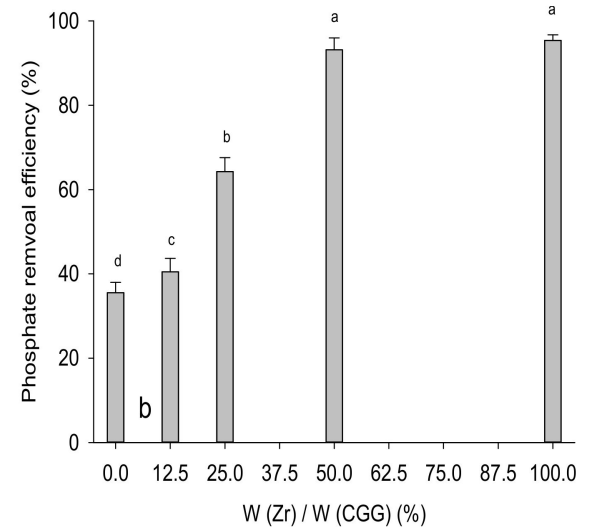

(b)

Figure 2. (a): Effect of different calcinated temperature $\left(300{ }^{\circ} \mathrm{C}, 400{ }^{\circ} \mathrm{C}, 500{ }^{\circ} \mathrm{C}, 600{ }^{\circ} \mathrm{C}, 700{ }^{\circ} \mathrm{C}, 800{ }^{\circ} \mathrm{C}\right)$ and (b): Effect of different $\mathrm{ZrOCl}_{2} \cdot 8 \mathrm{H}_{2} \mathrm{O} / \mathrm{CCG}$ mass ratio $(0 \%, 12.5 \%, 25.0 \%, 50 \%, 100 \%)$ on phosphate removal efficiency on phosphate removal efficiency (calcinated time: $10 \mathrm{~h}$, adsorbent: $20 \mathrm{~g} / \mathrm{L}$, particle size: $0.15 \mathrm{~mm}$, temperature: $15{ }^{\circ} \mathrm{C}$, stirring speed: $180 \mathrm{rpm}$, solution $\mathrm{pH}: 2.5$, adsorptive time: $2 \mathrm{~h}$ ). Different letters on the top of bars indicate significant differences between the treatments at $p<0.05$ according to S-N-K tests.

\subsection{Phosphate Adsorption Experiments}

\subsubsection{Effect of Contact Time}

Phosphate adsorption rapidly increased during the startup of the experiment reaching at equilibrium within $20 \mathrm{~min}$ and then leveled off with further increase in contact time (Figure 3). At maximum adsorption, phosphate removal rate of $93 \%$ was attained from the solution. The large number, oxidation states and array of different functional groups on the activated coal gangue (e.g., $\mathrm{Fe}_{2} \mathrm{O}_{3}, \mathrm{Al}_{2} \mathrm{O}_{3}, \mathrm{SiO}_{2}$ and zirconium oxide etc.) might be responsible for the high phosphate removal rate. Different types of adsorbent-adsorbate interactions may be involved in phosphate adsorption in current study. as reported by Liu et al. [19] and [20]. Apparently, CCG-Zr has potential application in the treatment of secondary effluents in terms of its strong adsorption for phosphate and high phosphate removal rate (Figure 3). Previously, Luo et al. [27] investigated phosphate adsorption onto $\mathrm{ZrOH}$ through some modification by ammonium. The FTIR results confirmed the mechanism of phosphate adsorption on the inner sphere complexes and ligand exchange electrostatic interactions. Further modifications by dimethylamine improved phosphate adsorption from $22.9 \%$ to $33.9 \%$ as proved by XPS. It was recommended that zirconium hydroxide presented the excellent performances of anti-interference in real wastewater [27]. 


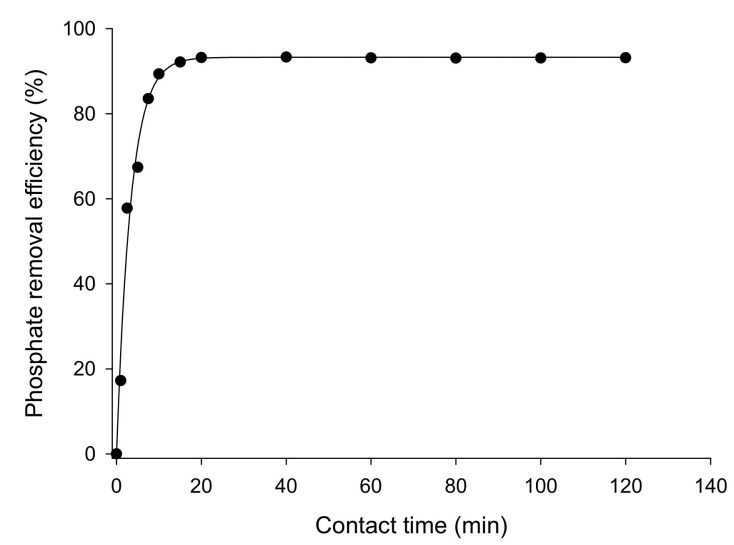

Figure 3. Effect of time on the efficiency of phosphate removal (initial phosphate concentration: $2.0 \mathrm{mg} / \mathrm{L}$, adsorbent dose: $20 \mathrm{~g} / \mathrm{L}$, temperature: $15^{\circ} \mathrm{C}$, stirring speed: $\left.180 \mathrm{rpm}, \mathrm{pH}: 2.5\right)$.

\subsubsection{Effect of $\mathrm{pH}$}

Solution $\mathrm{pH}$ is an important variable that influences phosphate adsorption. Various phosphate species present in water include $\mathrm{H}_{3} \mathrm{PO}_{4}, \mathrm{H}_{2} \mathrm{PO}_{4-}, \mathrm{HPO}_{4}{ }^{2-}$ and $\mathrm{PO}_{4}{ }^{3-}$, and their relative chemical proportions depend on solution $\mathrm{pH}$ [28]. The CCG-Zr could adsorb phosphate over a wide $\mathrm{pH}$ range of 2.5-9.5 (Figure 4). The maximum phosphate removal rate (98\%) was noted at $\mathrm{pH} 3.5$, decreased with increasing $\mathrm{pH}$, but still maintained around $72 \%$ at $\mathrm{pH} 9.5$, even at low phosphate concentrations $(2 \mathrm{mg} / \mathrm{L})$. A decrease in phosphate adsorption on the CCG-Zr may be attributed to an increase in net negative charge on the adsorbent surface and phosphate ions and subsequent repulsion between the adsorbent and phosphate ions [19,27]. However, activated $\mathrm{Al}_{2} \mathrm{O}_{3}$ and $\mathrm{CaO}$ in the CCG-Zr could remove phosphate from solution by chemical co-precipitation and cation bridging at a higher $\mathrm{pH}$ [29]. Therefore, the CCG-Zr could maintain a high phosphate removal rate $(>88 \%)$ from wastewater, even at $\mathrm{pH} 8.5$.

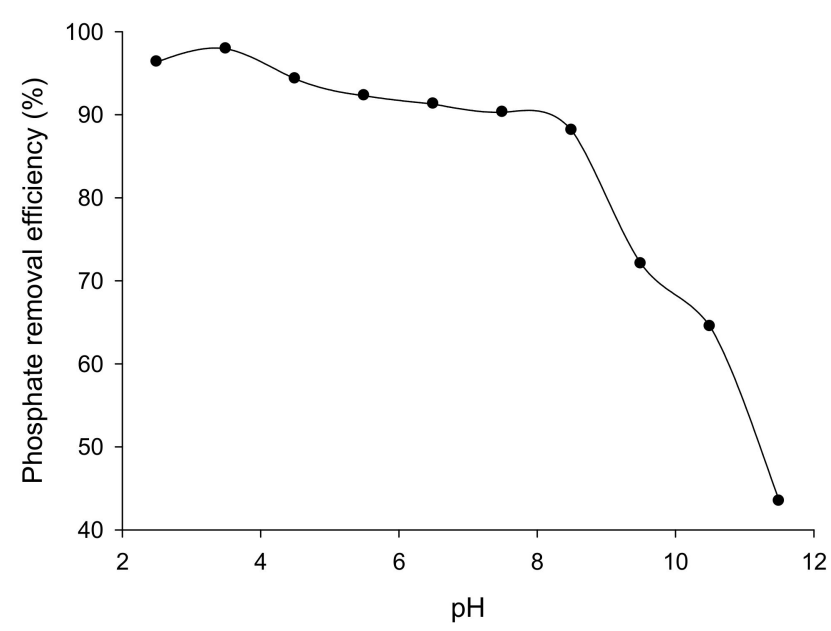

Figure 4. Effect of $\mathrm{pH}$ on the efficiency of phosphate removal (initial phosphate concentration: $2.0 \mathrm{mg} / \mathrm{L}$, adsorbent dose: $20 \mathrm{~g} / \mathrm{L}$, temperature: $15^{\circ} \mathrm{C}$, stirring speed: $180 \mathrm{rpm}$, time: $20 \mathrm{~min}$ ).

\subsubsection{Effect of Adsorbent Dose}

Phosphate removal rates generally had linear relationship with the adsorbent dose i.e. increased with increasing adsorbent dose and reached at the maximum (98\%) for CCG-Zr dosage of $20 \mathrm{~g} / \mathrm{L}$ (Figure 5). Phosphate removal rate tended to decrease with further increase in CCG-Zr dosage, but leveled off at $91 \%$ when adsorbent dosage was $60 \mathrm{~g} / \mathrm{L}$. A slight decrease in phosphate removal rate at higher adsorbent dosage may result from different phosphate sorption mechanisms involved in the 
phosphate removal process, adsorption being dominant at low dosages but precipitation at the higher adsorbent dosage.

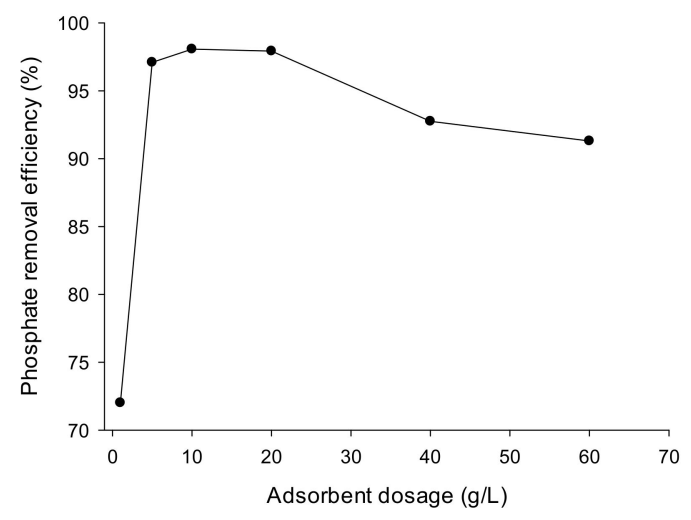

Figure 5. Effect of adsorbent dosage on phosphate removal by CCG-Zr (initial phosphate concentration: $2.0 \mathrm{mg} / \mathrm{L}, \mathrm{pH}: 3.5$, temperature: $15{ }^{\circ} \mathrm{C}$, stirring speed: $180 \mathrm{rpm}$, time: $20 \mathrm{~min}$ ).

\subsubsection{Effect of Phosphate Concentration}

The Langmuir and Freundlich models are often used to describe sorption isotherms of phosphate in wastewaters [5]. A linear form of the Langmuir and Freundlich equation [30] is expressed as:

$$
\begin{aligned}
& 1 / q_{e}=1 / q_{m} b c_{e}+1 / q_{m} \\
& \lg q_{e}=1 / n \lg c_{e}+\lg K_{F}
\end{aligned}
$$

where $\mathrm{q}_{\mathrm{e}}$ is the amount of phosphate adsorbed at equilibrium $(\mathrm{mg} / \mathrm{kg}), \mathrm{c}_{\mathrm{e}}$ is phosphate concentration at equilibrium $(\mathrm{mg} / \mathrm{L}), \mathrm{q}_{\mathrm{m}}$ is maximum adsorption of phosphate $(\mathrm{mg} / \mathrm{kg})$, and $\mathrm{b}$ is a constant related to phosphate binding energy on adsorbent $(\mathrm{L} / \mathrm{kg}) . \mathrm{K}_{\mathrm{F}}$ and $\mathrm{n}$ are constants related to adsorption characteristics in the Freundlich model.

The experimental data fitted well to the Langmuir and Freundlich equations, with correlation coefficients ranging from 0.96 to 0.97 . The estimated values of phosphate adsorption parameters obtained from these models were shown in Table 2. A high value $(n>1)$ indicated favorable adsorption. The calculated maximum adsorption capacity was $8.55 \mathrm{mg} / \mathrm{g}$ which is larger than that of amorphous zirconium hydroxide (2.5 mgP/g) [31], La doped vesuvianite (6.7 mg P/g) [32], or MgMn layered double hydroxides $(7.3 \mathrm{mg} \mathrm{P} / \mathrm{g})[33]$.

Table 2. Estimated isotherm parameters for phosphate adsorption on CCG-Zr.

\begin{tabular}{cccc}
\hline Adsorption Isotherms & Linear Forms & $\begin{array}{c}\text { Equation of } \\
\text { Linear Regression }\end{array}$ & $\begin{array}{c}\text { Parameters and } \\
\text { Correlation Coefficient }\end{array}$ \\
\hline Langmuir & $1 / \mathrm{q}_{\mathrm{e}}=1 /\left(\mathrm{bq}_{\mathrm{m}} \mathrm{C}_{\mathrm{e}}\right)+1 / \mathrm{q}_{\mathrm{m}}$ & $1 / \mathrm{q}_{\mathrm{e}}=1 /\left(\mathrm{bq}_{\mathrm{m}} \mathrm{C}_{\mathrm{e}}\right)+0.5906$ & $\mathrm{R} 2=0.9674$ \\
\hline Freundlich & $\ln \mathrm{q}_{\mathrm{e}}=1 / \mathrm{nln} \mathrm{C}_{\mathrm{e}}+\ln \mathrm{K}_{\mathrm{F}}$ & $\ln \mathrm{q}_{\mathrm{e}}=0.3188 \ln \mathrm{C}_{\mathrm{e}}+0.027$ & $\mathrm{R} 2=0.9747$ \\
\hline
\end{tabular}

The experimental data fitted better with the Freundlich $\left(R^{2}=0.9747\right)$ than Langmuir model $\left(R^{2}=0.9674\right)$, since the Freundlich equation assumes that the surface adsorption involves multilayer reactions. Besides adsorption; $\mathrm{Al}, \mathrm{Fe}, \mathrm{Ca}$ ions or oxides and some other components of CCG-Zr may also contribute to phosphate removal by precipitation to a certain extent.

\subsubsection{Regeneration of Adsorbent}

Regeneration of CCG-Zr is crucial for its economical application. $\mathrm{NaOH}$ was used to regenerate phosphate adsorbed on CCG-Zr (Figure 6) $(p<0.05)$. When the alkalinity reached $0.4 \mathrm{M}$, the maximum 
regeneration efficiency of $80 \%$ was achieved. The results indicated that this CCG-Zr could be regenerated and had a great potential to be used as an adsorbent for phosphate removal from secondary effluents.

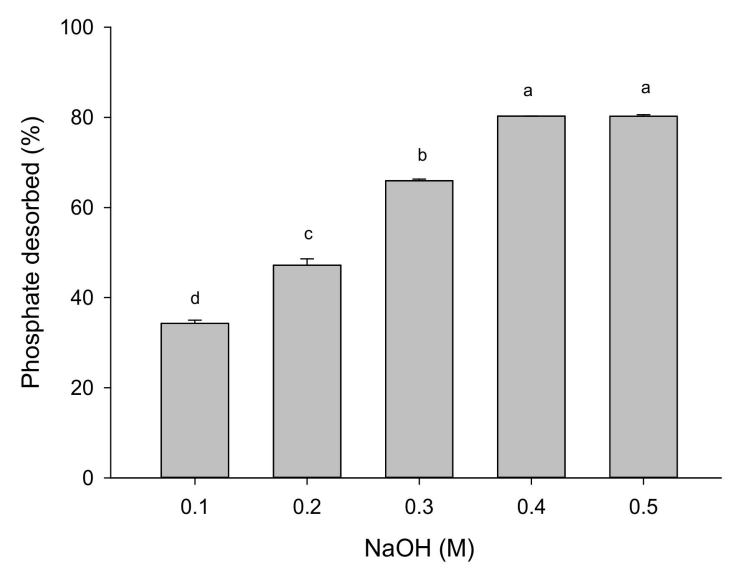

Figure 6. Desorption of phosphate from CCG-Zr (50\%) using different concentrations of $\mathrm{NaOH}$ solution (adsorbent dose: $20 \mathrm{~g} / \mathrm{L}$, stirring speed: $180 \mathrm{rpm}$, Temperature: $15^{\circ} \mathrm{C}$, time: $2 \mathrm{~h}$ ). Different letters on the top of bars indicate significant differences between the treatments at $p<0.05$ according to S-N-K tests.

\section{Conclusions}

This study indicated that the newly developed CCG-Zr had higher phosphate removal efficiencies compared with calcinated coal gangue. CCG-Zr could reach equilibrium phosphate removal rate for $2 \mathrm{mg} / \mathrm{L}$ of initial phosphate concentration within $20 \mathrm{~min}$. The CCG-Zr has a high removal rate of phosphate at low concentrations $(2 \mathrm{mg} / \mathrm{L})$ over a wide $\mathrm{pH}$ range. The adsorption isotherms fitted better to the Freundlich model than to the Langmuir model. The maximum phosphate adsorption capacity of the CCG-Zr was $8.55 \mathrm{mg} / \mathrm{g}$. It was demonstrated that $80 \%$ of the phosphate could be desorbed by using $\mathrm{NaOH}$. These results suggested that the CCG-Zr could be potentially applied for phosphate removal from secondary effluents.

Author Contributions: The authors collaborated on all parts of the research including framing of the study, collection and analysis of documents, and writing of the results.

Funding: This research received funding support from the Fundamental Research Funds for the Central Universities (Grant No. 2017XKZD13).

Acknowledgments: This study was supported by the Fundamental Research Funds for the Central Universities (Grant No. 2017XKZD13).

Conflicts of Interest: The authors declare no conflict of interest.

\section{References}

1. Li, C.; Ma, J.; Shen, J.; Wang, P. Removal of phosphate from secondary effluent with $\mathrm{Fe}^{2+}$ enhanced by $\mathrm{H}_{2} \mathrm{O}_{2}$ at nature $\mathrm{pH} /$ neutral pH. J. Hazard. Mater. 2009, 166, 891-896. [CrossRef]

2. Suzuki, T.M.; Bomani, J.O.; Matsunaga, H.; Yokoyama, T. Preparation of porous resin loaded with crystalline hydrous zirconium oxide and its application to the removal of arsenic. React. Funct. Polym. 2000, 43, 165-172. [CrossRef]

3. Xiao, X.; Liu, S.; Zhang, X.; Zheng, S. Phosphorus removal and recovery from secondary effluent in sewage treatment plant by magnetite mineral microparticles. Powder Technol. 2017, 306, 68-73. [CrossRef]

4. Wei, X.; Viadero, R.C., Jr.; Bhojappa, S. Phosphorus removal by acid mine drainage sludge from secondary effluents of municipal wastewater treatment plants. Water Res. 2008, 42, 3275-3284. [CrossRef]

5. Zeng, L.; Li, X.; Liu, J. Adsorptive removal of phosphate from aqueous solutions using iron oxide tailings. Water Res. 2004, 38, 1318-1326. [CrossRef]

6. Ou, E.; Zhou, J.; Mao, S.; Wang, J.; Xia, F.; Min, L. Highly efficient removal of phosphate by lanthanum-doped mesoporous SiO2. Colloids and Surfaces A. 2007, 308, 47-53. [CrossRef] 
7. Arshadi, M.; Foroughifard, S.; Gholtash, E.J.; Abbaspourrad, A. Preparation of iron nanoparticles-loaded Spondias purpurea seed waste as an excellent adsorbent for removal of phosphate from synthetic and natural waters. J. Colloid Interface Sci. 2015, 452, 69-77. [CrossRef]

8. Park, T.; Ampunan, V.; Maeng, S.; Chung, E. Application of steel slag coated with sodium hydroxide to enhance precipitation-coagulation for phosphorus removal. Chemosphere 2017, 167, 91-97. [CrossRef] [PubMed]

9. Mortula, M.M.; Gagnon, G.A. Phosphorus treatment of secondary municipal effluent using oven-dried alum residual. J. Environ. Sci. Heal. A 2007, 42, 1685-1691. [CrossRef]

10. Zhou, C.; Liu, G.; Wu, S.; Lam, P.K. The environmental characteristics of usage of coal gangue in bricking-making: a case study at Huainan, China. Chemosphere 2014, 95, 274-280. [CrossRef]

11. Bian, Z.; Dong, J.; Lei, S.; Leng, H.; Mu, S.; Wang, H. The impact of disposal and treatment of coal mining wastes on environment and farmland. Environ. Geol. 2008, 58, 625-634. [CrossRef]

12. Jiang, X.; Lu, W.X.; Zhao, H.Q.; Yang, Q.C.; Yang, Z.P. Potential ecological risk assessment and prediction of soil heavy-metal pollution around coal gangue dump. Nat. Hazards Earth Syst. Sci. 2014, 14, 1599-1610. [CrossRef]

13. Liu, B.; Tang, Z.; Dong, S.; Wang, L.; Liu, D. Vegetation recovery and groundwater pollution control of coal gangue field in a semi-arid area for a field application. Int. Biodeter. Biodegr. 2018, 128, 134-140. [CrossRef]

14. Tang, Q.; Li, L.; Zhang, S.; Zheng, L.; Miao, C. Characterization of heavy metals in coal gangue-reclaimed soils from a coal mining area. J. Geochem. Explor. 2018, 186, 1-11. [CrossRef]

15. Ding, W.; Bai, S.; Mu, H.; Naren, G. Investigation of phosphate removal from aqueous solution by both coal gangues. Water Sci. Technol. 2017, 76, 785-792. [CrossRef]

16. Dong, L.; Liang, X.; Song, Q.; Gao, G.; Song, L.; Shu, Y.; Shu, X. Study on Al2O3 extraction from activated coal gangue under different calcination atmospheres. J. Therm. Sci. 2017, 26, 570-576. [CrossRef]

17. Chen, L.; Zhao, X.; Pan, B.; Zhang, W.; Hua, M.; Lv, L.; Zhang, W. Preferable removal of phosphate from water using hydrous zirconium oxide-based nanocomposite of high stability. J. Hazard. Mater. 2015, 284, 35-42. [CrossRef]

18. Lin, K.-Y.A.; Chen, S.-Y.; Jochems, A.P. Zirconium-based metal organic frameworks: Highly selective adsorbents for removal of phosphate from water and urine. Mater. Chem. Phys. 2015, 160, 168-176. [CrossRef]

19. Liu, H.; Sun, X.; Yin, C.; Hu, C. Removal of phosphate by mesoporous ZrO2. J. Hazard. Mater. 2008, 151, 616-622. [CrossRef] [PubMed]

20. Mortula, M.M.; Gibbons, M.; Gagnon, G. Phosphorus adsorption by naturally-occurring materials and industrial by-products. J. Environ. Eng. Sci. 2007, 6, 157-164. [CrossRef]

21. Pitakteeratham, N.; Hafuka, A.; Satoh, H.; Watanabe, Y. High efficiency removal of phosphate from water by zirconium sulfate-surfactant micelle mesostructured immobilized on polymer matrix. Water Res. 2013, 47, 3583-3590. [CrossRef] [PubMed]

22. Tang, Y.; Zong, E.; Wan, H.; Xu, Z.; Zheng, S.; Zhu, D. Zirconia functionalized SBA-15 as effective adsorbent for phosphate removal. Micropor. Mesopor. Mat. 2012, 155, 192-200. [CrossRef]

23. Zong, E.; Wei, D.; Wan, H.; Zheng, S.; Xu, Z.; Zhu, D. Adsorptive removal of phosphate ions from aqueous solution using zirconia-functionalized graphite oxide. Chem. Eng. J. 2013, 221, 193-203. [CrossRef]

24. Cao, Z.; Cao, Y.; Dong, H.; Zhang, J.; Sun, C. Effect of calcination condition on the microstructure and pozzolanic activity of calcined coal gangue. Int. J. Miner. Process. 2016, 146, 23-28. [CrossRef]

25. APHA. Standard Methods for the Examination of Water and Wastewater, 20th ed.; American Public Health Association/American Water Works Association/Water Environment Federation: Washington, DC, USA, 1998.

26. Mondal, A.; Ram, S. Formation of a new polymorph of $\mathrm{ZrO}_{2}$ with orthorhombic crystal structure contained in a mesoporous structure. Chem. Phys. Lett. 2003, 382, 297-306. [CrossRef]

27. Luo, X.; Wu, X.; Reng, Z.; Min, X.; Xiao, X.; Luo, J. Enhancement of phosphate adsorption on zirconium hydroxide by ammonium modification. Ind. Eng. Chem. Res. 2017, 56, 9419-9428. [CrossRef]

28. Pan, B.; Wu, J.; Pan, B.; Lv, L.; Zhang, W.; Xiao, L.; Wang, X.; Tao, X.; Zheng, S. Development of polymer-based nanosized hydrated ferric oxides (HFOs) for enhanced phosphate removal from waste effluents. Water Res. 2009, 43, 4421-4429. [CrossRef] [PubMed] 
29. Liu, X.; Zhang, L. Removal of phosphate anions using the modified chitosan beads: Adsorption kinetic, isotherm and mechanism studies. Powder Technol. 2015, 277, 112-119. [CrossRef]

30. Shi, Z.L.; Liu, F.M.; Yao, S.H. Adsorptive removal of phosphate from aqueous solutions using activated carbon loaded with Fe (III) oxide. New Carbon Mater. 2011, 26, 299-306. [CrossRef]

31. Chitrakar, R.; Tezuka, S.; Sonoda, A.; Sakane, K.; Ooi, K.; Hirotsu, T. Selective adsorption of phosphate from seawatr and wastewater by amorphous zirconium hydroxde. J. Colloid Interface Sci. 2006, 297, 426-433. [CrossRef]

32. Li, H.; Ru, J.Y.; Liu, X.H.; Wang, J.Q.; Zhang, W.D. Removal of phosphate from polluted water by lanthanum doped vesurianite. J. Hazard. Mater. 2009, 168, 326-330. [CrossRef] [PubMed]

33. Chitrakar, R.; Tezuka, S.; Sonada, A.; Sakane, K.; Ooi, K.; Hirotsu, T. Adsorption of phosphate from seawater on calcinated MgMn-layered double hydroxides. J. Colloid Interface Sci. 2005, 290, 45-51. [CrossRef] [PubMed]

C 2019 by the authors. Licensee MDPI, Basel, Switzerland. This article is an open access article distributed under the terms and conditions of the Creative Commons Attribution (CC BY) license (http://creativecommons.org/licenses/by/4.0/). 